ISSN 0258-7122

Bangladesh J. Agril. Res. 33(3) : 427-438, September 2008

\title{
MANGO MARKETING SYSTEM IN SELECTED AREAS OF BANGLADESH
}

\author{
M.A.MATIN ${ }^{1}$, M.A. BASET ${ }^{2}$, Q.M ALAM ${ }^{3}$ \\ M.R. KARIM ${ }^{4}$ AND M.R. HASAN ${ }^{5}$
}

\begin{abstract}
This study was carried out to identify the most efficient and suitable marketing channels of mango in some selected areas of Bangladesh by using primary data collected randomly from 90 farmers and 55 traders. Out of 55 traders, 15 were Bairals, 15 were Beparis. 9 Aratdar (local), 6 Aratdar (urban), 10 Retailers (both local and urban). According to the volume of mango handled and longevity or participation of the intermediaries in the channel, five major channels were identified as dominant in the study areas. The channel Farmer Bairal- BepariAratdar (Dhaka)-Retailer (Dhaka)-Consumer ranked first. The results showed that channel V, Farmer-Retailer Consumer, possesses the highest marketing efficiency followed by channel IV, III, and II. The performance indicators revealed that the channel I and channel II were not relatively efficient in the mango producing regions. Unstable price of mango was the first rank problem in the study area. Establishment of mango processing plant in the intensive growing areas may be the remedy of the problem, which will ensure fair prices for the farmer.
\end{abstract}

Key Words: Mango marketing, channels, problem.

\section{Introduction}

Mango (Mangifera indica L) is one of the important fruits of Bangladesh. The area under mango cultivation during 2003-04 was about 50991 hectares with a total production of about 242605 metric tons (BBS, 2004). There are some intensive mango growing areas in Bangladesh where mango produced commercially and as well as marketed in other areas of the country. Mango needs to be moved along a distance to reach the ultimate consumers under the prevailing marketing system. It is not perceived that the producers are not getting full benefit of higher prices prevailed in the market, if the mango farmers do not get the benefit from higher prices, their net return per unit area will be less and it will continue to decrease with the adoption of improved technology. If it is not, their net return, per unit area would be decreased with the adoption of improved technology. Mangos are bulky and highly perishable in nature and preserving them in the cold storage is not always possible on account of high cost involved

\footnotetext{
${ }^{1}$ Senior Scientific Officer, ${ }^{2 \& 4}$ Principal Scientific Officer, ${ }^{3}$ Chief Scientific Officer and ${ }^{5}$ Scientific Officer, Agricultural Economics Division, BARI, Joydebpur, Gazipur-1701, Bangladesh.
} 
with it. Hence, spoilage of mango during transportation as well as during sales is quite high. In the peak period, there is an excess supply creating a glut in the market and causing a fall in the price and affecting the incomes of the farmers. As a result, the growers are not getting their due returns for their produce and the country is being deprived of potential resources.

Marketing plays an important role not only in stimulating production but also in accelerating the pace of economic development. Efficient marketing system usually ensures higher level of producer's share, reducing the number of middlemen and restricting the marketing charges, mal-practices during marketing of farm products. It is, therefore, essential to explore the efficient marketing channels and to suggest the producers the channels for obtaining optimum prices of their farm produce. So far, very few mango researches have been done, especially on marketing aspects of mango in this country. Keeping this in view, the present study was undertaken to analyze the marketing of mango in selected areas of Bangladesh. Hence, the present study has been conducted with the following specific objectives:

i) to examine the economic efficiency of various mango-marketing channels through selected indicators and thereby determine the most efficient and suitable marketing Channel in the study areas and

ii) to identify the problems of marketing both at farmers' and traders' level.

\section{Materials and Method}

Three important mango growing areas, namely Dinajpur, Chapai Nwabgonj and Meherpur districts were selected for the present study. Within the districts, Dinajpur sadar of Dinajpur, Meherpur sadar of Meherpur, Sibgonj thana of Chapai Nwabjonj were purposively selected for the study. Two villages of each upaiila were selected with the help of agricultural extension personnel. From the selected villages, a list of mango growers was prepared. Total ninety farmers were selected randomly taking 30 farmers from each district. The intermediaries involved in the mango marketing were categorized into 5 groups viz., Bairals, Beparis, Aratdars (both local and urban), retailers (both local and urban). One primary and one secondary market were selected from each growing areas. From these production area, mango goes to the markets of Dhaka, Chittagong, and Khulna, Mymensingh and Comilla and other areas of the country. Wholesale and retail markets were selected from Dhaka and Gazipur, which were the major consuming areas. A list of intermediaries was prepared from the selected areas. From the list, 55 intermediaries were selected for this study. Out of 55 traders, 15 were Bairals, 15 were Beparies, 9 were Aratdar (local), 6 were Aratdar (urban) 
and 10 were retailers. Simple random sampling technique was used to select the farmers and intermediaries. Data were collected during the period of June to August 2005.

\section{Analytical Technique}

\section{Marketing margin}

Marketing margin included marketing cost and profit or loss of all interediaries in the marketing chain. For determining marketing margin of any commodity, the following formula was used

$\mathrm{GM}_{\mathrm{i}}=\mathrm{P}_{\mathrm{Ri}}-\mathrm{P}_{\mathrm{Pi}}$

Where,

$\mathrm{GM}_{\mathrm{i}}=$ Gross margin (Tk/quintal) for $\mathrm{i}^{\text {th }}$ intermediary

$\mathrm{PR}_{\mathrm{i}}=$ Price received (Tk/quintal) by $\mathrm{i}^{\text {th }}$ intermediary

$\mathrm{PP}_{\mathrm{i}}=$ Price paid (Tk/quintal) by $\mathrm{i}^{\text {th }}$ intermediary

$\mathrm{NM}_{1}=\mathrm{GM}_{\mathrm{i}}-\mathrm{MC}_{\mathrm{i}}$

Where,

$\mathrm{NM}_{\mathrm{i}}=$ Net margin (Tk/quintal) for $\mathrm{i}^{\text {th }}$ intermediary

$\mathrm{Mc}_{\mathrm{i}}=$ Marketing cost incurred (Tk/quintal) for $\mathrm{i}^{\text {th }}$ intermediary

\section{Marketing efficiency measure}

Five performance indicators were used for measuring different marketing channels. These indicators are (i) Percent of product run through the channel $\left(\mathrm{I}_{1}\right)$. (ii) Producer's share $\left(\mathrm{I}_{2}\right)$, (iii) Marketing cost ( $\left.\mathrm{I}_{3}\right)$, (iv) Middle mens' margin $\left(\mathrm{I}_{4}\right)$,

(v) Price deviation i.e. differences of maximum and minimum prices of mango in a month $\left(\mathrm{I}_{5}\right)$ (Chauhan et al., 1994)

The Producer's share was derived by the ratio of net average price received by the producers' to the weighted average price of mango which was calculated with the following formula and the channel which had highest producer's share was ranked (1) as first and vice versa.

Percentage of producer's share $=\frac{p_{p i}}{p_{r i}} \times 100$ 
Where,

$\mathrm{P}_{\mathrm{pi}}=$ Producers' share in the $\mathrm{i}^{\text {th }}$ channel

$\mathrm{P}_{\mathrm{ri}}=$ Average price of mango at the retail level in each channel.

$\mathrm{i}=$ Number of channels $(\mathrm{i}=1,2,-, \mathrm{n})$

The cost of marketing was calculated and the lowest cost marketing channel was ranked I and that which has highest cost as the last. The same approach was followed in ranking the margin of middlemen in each channel. The deviation ( d) between the highest and lowest prices in each month in the respective channels were computed. The price equalization among all the categories of farmers denote $d=0$. That is, there is no price deviation among the farmers' prices. If the differences are high, it implies highest price deviation and vice-versa. The final ranking of all the six indicators of all channels were computed by using the composite index formula.

$R=\frac{R_{i}}{N_{i}}$

Where,

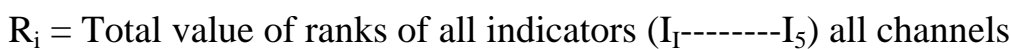

$\mathrm{N}_{\mathrm{i}}=$ Number of indicators.

The lowest mean represents the most efficient channel and vce versa (Rajagopal, 1986).

\section{Results and Discussion}

\section{Marketing channels}

Marketing channels are the alternative roots of products flow from producers to consumers (Kohls and Uhl, 1980). In the study areas, the mango moved from the producer seller to the consumers through some market intermediaries, such as Bairals, Beparis, Aratdars (both local and urban) and retailers (both local and urban). According to the volume of mango handled and participation of the intermediaries in the channel, five channels were identified as dominant in the study areas as shown in Table 1 . So, the efficiency of the following major channels were measured.

\section{Intermediaries involved in mango marketing channel}

\section{Bairal}

The people who have no own orchard land but inolved in mango business are Bairal. They are the advance buyers of mangos. They are doing their business all 
over mango growing centers and making the business competitive. Frequent hazardous weather and attack by mango hopers during the flowering and fruit setting stage make the crop very uncertain. Therefore, in order to avoid the risk and uncertainty of the crop, most of the farmers in the selected districts sell their expected crop at the time of fruit setting on even before on the basis of estimation formed from the amount of bloom to the classified advance buyers locally known as Bairal. Bairal are doing business with little capital of their own and some times borrowing the capital from Aratdars.

\section{$\underline{\text { Beparis }}$}

Beparis are of two kinds. They are either local or coming from other districts Like Dhaka, Chittagong, and Khulna, etc. They buy harvested mango from fhrmers and Bairals in the local markets through the local Aratdar. The Beparies usually sell mango to the retailers in the local market or dispatch it to Aratdar of other big markets. They arc doing their business in-group. In some cases, they borrow money from the dealing Aratdar.

Table 1. Mango run through the major channels in selected areas.

\begin{tabular}{|l|l|c|c|}
\hline & \multicolumn{1}{|c|}{ Marketing Channels } & $\begin{array}{c}\text { Percent of } \\
\text { product run }\end{array}$ & Rank (I) \\
\hline I. & $\begin{array}{l}\text { Farmer - Bairal - Bepari - Aratdar (Local) - } \\
\text { Aratdar (Dhaka)-Retailer (Dhaka)-Consumer }\end{array}$ & 25.00 & 1 \\
\hline II. & $\begin{array}{l}\text { Farmer - Bepari - Aratdar (Local) -Aratdar } \\
\text { (Dhaka) - Retailer (Dhaka)-Consumer }\end{array}$ & 20.00 & 2 \\
\hline III. & $\begin{array}{l}\text { Farmer - Bepari- Aratdar (Local) - Aratdar - } \\
\text { (Other district) -Retailer (Other district)- } \\
\text { Consumer }\end{array}$ & 15.00 & 3 \\
\hline IV. & $\begin{array}{l}\text { Farmer - Retailer (Other district)- Aratdar (Local) } \\
\text { - Retailer (Othe district) - Consumer }\end{array}$ & 13.00 & 4 \\
\hline V. & Farmer - Retailer(Local) - Consumer & 2.00 & 5 \\
\hline
\end{tabular}

\section{$\underline{\text { Aratdar }}$}

Aratdar are big traders. They are commission agent and have fixed establishment in the market and operated between Bairals, Beparies, and Retailers. The charged fixed fees and commission from the Beparies and Retailers.

\section{$\underline{\text { Retailer }}$}

Retailer was last link in the mango marketing. There are two types of retailers rural retailer's and urban retailer's. Rural retailers sell their mango in different local markets and urban Retailers sell at with permanent shops in the urban areas. 
They bought mango from the Beparies through Aratdar and sell it to the urban residents, the ultimate consumers.

\section{Cost of marketing by Farmer}

The per quintal marketing cost of mango by farmer was Tk. 133.42. Among the cost items, transportation cost incurred the major share, which was about 45 percent followed by harvesting cost (Table 2). Bargaining method was used to fix price. Farmers in the study areas used van and rickshaw to carry mango in the markets. In the study areas, they used van and rickshaw with a distance of 488 and $5.12 \mathrm{Km}$, respectively.

Table 2. Cost of mango marketing by farmer.

\begin{tabular}{l|l|l}
\hline \multicolumn{1}{c|}{ Cost item } & $\begin{array}{r}\text { Average cost } \\
\text { (Tk./quintal) }\end{array}$ & $\begin{array}{c}\text { Percent of total } \\
\text { cost }\end{array}$ \\
\hline Harvesting & 32.31 & 24.22 \\
Grading & 12.16 & 9.11 \\
Packing/Basket & 6.00 & 4.50 \\
Loading & 2.12 & 1.59 \\
Transportation & 59.42 & 44.54 \\
Market tolls & 6.25 & 4.68 \\
Donation & 5.00 & 3.75 \\
Entertainment/ personal expenses & 10.16 & 7.61 \\
\hline Total cost & 133.42 & 100.00 \\
\hline
\end{tabular}

\section{Cost of marketing by Intermediaries}

Knowledge of the distribution of' marketing costs among various intermediaries is very important for improving the efficiency of marketing system. Nature and extent of marketing cost varies from traders to traders. The marketing cost included the cost of transportation, cleaning, grading, binding, loading, and unloading, tools and entertainment for the traders. Average marketing cost per quintal of mango were calculated as Tk. 128.49 for Bairal, Tk. 446.03 for Bepari. Tk. 231.11 for Retailer (other district), Tk. 237.07 for Retailer (Dhaka), Tk. 98.08 for Retailer (Local), Tk. 18.92 for Aratdar (local) and Tk. 25.16 for Aratdar (Dhaka and Tk. 22.36 for Aratdar (Other districts). Cost of marketing for Beparis as the highest among the intermediaries due to high transportation cost, loading and unloading, tool \& taxes etc. Commission is the highest cost item followed by transportation cost at Bepari level. lowest cost was found for Aratdar (local). 
Table 3. Marketing cost of mango in different intormediaries.

\begin{tabular}{|c|c|c|c|c|c|c|c|c|}
\hline Items & Bairal & Bepari & $\begin{array}{l}\text { Retailer } \\
\text { (Dhka) }\end{array}$ & $\begin{array}{l}\text { Retailer } \\
\text { (other) }\end{array}$ & $\begin{array}{l}\text { Retailer } \\
\text { (local) }\end{array}$ & $\begin{array}{l}\text { Aratdar } \\
\text { (Dhaka) }\end{array}$ & $\begin{array}{l}\text { Aratdar } \\
\text { (other) }\end{array}$ & $\begin{array}{l}\text { Retailer } \\
\text { (local) }\end{array}$ \\
\hline Transportation & 55.16 & 109.33 & 32.18 & 37.21 & - & - & - & 10.20 \\
\hline Grading & 14.84 & & & & - & - & - & \\
\hline $\begin{array}{l}\text { Binding \& Packing \& } \\
\text { Weighing }\end{array}$ & 6.00 & 6.00 & & & - & - & - & \\
\hline $\begin{array}{l}\text { Loading \& Unloading } \\
\text { (Transport to Aratdar) }\end{array}$ & 3.00 & 24.72 & 6.12 & 6.12 & - & - & - & 3.78 \\
\hline Labour Wages & - & - & & - & 0.84 & 1.76 & 0.84 & - \\
\hline Salaries to employees & - & - & & - & 6.86 & 7.24 & 7.86 & - \\
\hline Wastage & - & - & & & - & - & & - \\
\hline Commission & - & 133.11 & 187.00 & 176.00 & - & - & & - \\
\hline Rent & & - & & & - & - & & - \\
\hline Tools and Taxes & 6.25 & - & 5.16 & 5.16 & - & - & & - \\
\hline $\begin{array}{l}\text { Entertainment } \\
\text { perosnal edxpense }\end{array}$ & 8.32 & 6.50 & 2.11 & 2.11 & 4.46 & 5.00 & 5.46 & 6.03 \\
\hline Electricity & - & - & 1.00 & 1.00 & 0.68 & 1.61 & 0.68 & 1.10 \\
\hline Tips \& donation & 5.40 & - & - & - & - & - & - & 0.60 \\
\hline Mis (Tel, etc) & - & - & - & - & - & - & - & - \\
\hline Harvestion & 30.19 & - & - & - & - & - & - & - \\
\hline Cage & - & 58.33 & - & - & - & - & - & - \\
\hline Gunny bag & - & 20.28 & - & - & - & - & - & - \\
\hline Straw & - & 5.14 & - & - & - & - & - & - \\
\hline Rof & - & 3.61 & - & - & - & - & - & - \\
\hline Paper & - & 2.18 & - & - & - & - & - & - \\
\hline $\begin{array}{l}\text { Labour Charge for } \\
\text { basket }\end{array}$ & - & 21.67 & - & - & - & - & - & \\
\hline Davage & - & 57.00 & - & - & - & - & & 36.72 \\
\hline Telephone & - & 1.00 & - & - & 2.69 & 3.69 & 2.71 & - \\
\hline Subscription & - & 3.16 & - & - & - & - & - & - \\
\hline Sweeter & - & - & .80 & .80 & - & - & - & 0.70 \\
\hline Storage & - & - & 2.70 & 2.70 & - & - & - & - \\
\hline other & - & - & - & & 2.00 & 2.11 & 3.40 & 0.60 \\
\hline Total & 128.49 & 446.03 & 237.07 & 231.11 & 18.92 & 25.16 & 22.36 & 93.08 \\
\hline
\end{tabular}

Channel-wise marketing cost is shown in Table 4. It was observed that the channel I had the highest marketing cost (Tk. 855.67/quintal) followed by channel II, III, and IV. Lowest cost (Tk. 98.08) was found in channel V. High cost of transportation, loading and unloading and commission paid to Araldar were the main reasons for higher marketing cost. Highest number of intermediaries were involved in channel I that was the main reasons for higher marketing cost. 
Table 4. Marketing cost of mango in different channels.

\begin{tabular}{l|l|l|l|l|l}
\hline \multirow{2}{*}{ Items } & \multicolumn{5}{c}{ Channel } \\
\cline { 2 - 7 } & \multicolumn{1}{c}{ I } & \multicolumn{1}{c}{ II } & \multicolumn{1}{c}{ III } & \multicolumn{1}{c}{ IV } & \multicolumn{1}{c}{ V } \\
\hline Transportation & 196.67 & 141.51 & 146.54 & 37.21 & 40.2 \\
Grading & 14.84 & 9.11 & 10.16 & 1.68 & - \\
Binding \& Packing & 117.21 & 117.21 & 117.21 & 6.00 & - \\
Loading \& Unloading & 33.84 & 30.84 & 30.84 & 1.10 & 3.78 \\
Tools \& Taxes & 11.41 & 5.16 & 6.00 & 198 & 6.19 \\
Commission & 320.11 & 320.11 & 309.11 & 176.00 & - \\
Salary & 14.10 & 14.10 & 14.11 & - & - \\
Labour wages & 2.60 & 2.60 & 2.71 & - & - \\
Tips \& Donation & 8.56 & 8.32 & 4.18 & 2.53 & 0.60 \\
Damage \& Spoilage & 61.00 & 50.08 & 55.47 & 20.30 & 36.72 \\
Sweeper & 0.80 & 0.80 & 0.62 & 0.69 & 0.70 \\
Shop rent & 5.14 & 5.14 & 4.13 & 2.12 & 2.68 \\
Telephone & 7.38 & 6.90 & 4.68 & 0.72 & - \\
Entertainment & 26.39 & 10.31 & 8.62 & 3.16 & 6.03 \\
Storage Charge & 4.03 & 3.50 & 2.72 & - & - \\
Harvesting cost & 30.19 & - & - & - & - \\
Electricity & 1.29 & 1.38 & 1.16 & 0.69 & 1.10 \\
Other & 0.11 & 0.11 & 0.16 & 0.6336 & 0.06 \\
\hline Total & 855.67 & 727.18 & 718.42 & 253.47 & 98.02 \\
\hline & & & & & \\
\hline
\end{tabular}

\section{Farmers' shares to consumers' price}

Table 5 shows the producers' share of mango in different marketing channels. Farmer's share of mango in different marketing channels was the highest in channel V (the shortest route), followed by channel IV, and channels III and was lowest in channel I (the longest route). Channel I had the lowest share for the producer. Unnecessary marketing tiers develops when there is market imperfection or producer-seller are unorganized and while there is lack of market information or the cost of gathering information is high.

\section{Marketing cost and margins of the middlemen under different channels}

Table 6 shows that the channel I of mango marketing has to incur the highest marketing cost whereas, the cost is the lowest in case of channel $\mathrm{V}$ (the shortest route). It reveals if farmers sell their mango through Beparis who take the product to Aratdar and then pass to Retailar, the marketing cost becomes high (channel I). On the other hand, if farmers sell their mango directly to the Retailar by passing the Aratdar then the marketing cost is the lowest (channel V). Number 
of intermediaries and marketing tiers is a major factor in increasing or decreasing marketing cost.

Table 5. Producers' share in mango price in different marketing channels.

\begin{tabular}{lllll|ll}
\hline Particulars & Channel I & Channel II & Channel III & Channel IV & Channel V \\
\hline $\begin{array}{l}\text { Producer's price } \\
\begin{array}{l}\text { Weighted average price at } \\
\text { the retail level }\end{array}\end{array}$ & 3914 & 2332 & 2382 & 2408 & 2488 \\
$\begin{array}{l}\text { Percentage of producers' } \\
\text { share }\end{array}$ & 60.78 & 60.22 & 62.42 & 63.38 & 66.48 \\
Rank $\left(\mathrm{I}_{\mathrm{i}}\right)$ & 5 & 4 & 3816 & 3799 & 3742 \\
\hline
\end{tabular}

Table 6 also shows that the marketing margin of intermediaries of different channels. It reveals that the highest margin is in channel I and the lowest is in channel $\mathrm{V}$. The highest margin is due to a large number of intermediaries involved in this channel as compared to other channels. Large number of intermediaries in mango marketing increase marketing cost and margin. So, the number of intermediaries involved in mango marketing should be reduced, but it would not be feasible to eliminate all of the intermediaries from the channel of mango marketing.

Table 6. Marketing costs and margins of the middlemen under different channels.

\begin{tabular}{llllllll}
\hline Particulars & Channel I & Channel II & Channel III & Channel IV & Channel V \\
\hline Purchase Price & 2379 & 2332 & 2382 & 2408 & 2488 \\
Sale Price & 3914 & 3872 & 3816 & 3799 & 3742 \\
Marketing Margin $\left(\mathrm{I}_{3}\right)$ & 1535 & 1540 & 1434 & 1391 & 1254 \\
& 5 & 4 & 3 & 2 & 1 \\
Marketing cost $\left(\mathrm{I}_{2}\right)$ & 855.67 & 727.18 & 718.42 & 253.47 & 98.08 \\
& 5 & 4 & 3 & 2 & 1 \\
Net Margin & 679.33 & 812.82 & 715.58 & 1137.53 & 1155.92 \\
\hline
\end{tabular}

Source: Field Survey

\section{Deviation between maximum and minimum prices}

Table 7 shows the price deviation of different channels for each month. Price deviation means the differences of maximum and minimum prices in a month. The differences between maximum and minimum prices of each month were calculated and finally the differences of all months were summed up and then the average deviation was calculated. It may be observed from table that channel V incurred lowest price deviation followed by IV and III. Price deviation was highest in channel II. It might be the reason of demand and supply condition of 
the firmer. The traders availed of this opportunity and made price discrimination. Perishable nature of mango is another reason of high deviation of prices.

Table 7. Deviation between maximum and minimum price in different channels.

\begin{tabular}{ll|llll|l}
\hline Month & Channel I & Channel II & Channel III & Channel IV & Channel V \\
\hline June & 132 & 148 & 84 & 166 & 105 \\
July & 212 & 200 & 190 & 108 & 936 \\
August & 98 & 104 & 1369 & 72 & 136 \\
$\sum$ d & 442 & 452 & 410 & 346 & 337 \\
D & 147.33 & 150.66 & 136.66 & 115.33 & 112.33 \\
N & 3 & 3 & 3 & 3 & 3 \\
\hline Rank $\left(\mathrm{I}_{4}\right)$ & 4 & 5 & 3 & 2 & 1 \\
\hline
\end{tabular}

$\mathrm{N}=$ Total number of month (3 month)

$\mathrm{D}=$ The deviation between the highest and lowest prices in each month in the respective channel

\section{Channel efficiency measures}

The efficiency of different marketing channels was drawn on the basis of ranks of different performance indicators in different channels using composite index formula. The performance indicators revealed that the channel II and I were not relatively efficient in the agricultural marketing sectors in mango producing regions. It was due to low prices received by the farmers in the channel I and II as compared to other channels. The farmers' response to the marketing channel $\mathrm{V}$, selling mango directly to the Retailers showed to be the most desirable. It may be concluded from the foregoing analysis that farmers shares seemed to be very low in channel (I and II), while the cost of marketing and middleman's margins were high in these channels.

If the farmers' would sell their mango through channel $\mathrm{V}$ then the profit would be highest. But farmers sell small amount of mango in this channel and they cannot store mango for long time because of the problem of spoilage. It can be concluded that channel I was benefited for the farmer because highest amount of mango sell in this channel. Total amount of return were also earned in this channel and distance consumer would be benefited for availability of mango to them. Middlemen were working for available of mango to the ultimate consumer. But when market imperfection or producer-seller are unorganized, then middlemen would take the benefit of abnormal profit. 
Table 8. Efficiency of marketing channels.

\begin{tabular}{|c|c|c|c|c|c|c|c|}
\hline \multirow[t]{2}{*}{ Marketing Channel } & \multicolumn{5}{|c|}{ Performance indiator } & \multirow{2}{*}{$\begin{array}{c}\text { Composite } \\
\text { index }\left(\mathrm{R}_{\mathrm{i}} / \mathrm{N}_{\mathrm{i}}\right)\end{array}$} & \multirow{2}{*}{$\begin{array}{c}\text { Final } \\
\text { Ranking }\end{array}$} \\
\hline & $\mathrm{I}_{1}$ & $\mathrm{I}_{2}$ & $\mathrm{I}_{3}$ & $\mathrm{I}_{4}$ & $\mathrm{I}_{5}$ & & \\
\hline I & 1 & 5 & 5 & 5 & 4 & 4.00 & 5 \\
\hline II & 2 & 4 & 4 & 4 & 5 & 3.80 & 4 \\
\hline III & 3 & 3 & 3 & 3 & 3 & 3.00 & 3 \\
\hline IV & 4 & 2 & 2 & 2 & 2 & 2.40 & 2 \\
\hline
\end{tabular}

$R_{i}=$ Total value of the ranks of performance indicators.

$\mathrm{N}_{\mathrm{i}}=$ Total number of performance

\section{Problems of mango marketing}

Several problems were found for farmers and traders and presented in Table 9. The problems were categorized on the basis of priority ranking. Seven problems are identified for the farmers. Among the problems, inadequate transport facility ranked first followed by higher cost of transportation and preservation problem. In the case of traders, unstable price was the first ranked problem followed by selling on credit.

Table 9. Marketing problems of farmers and traders.

\begin{tabular}{l|l}
\hline \multicolumn{1}{c}{ Problems } & \\
\hline A. Farmers & 1 \\
Inadequate transport facility & 2 \\
Higher cost of transportation & 3 \\
Preservation problem & 4 \\
Lack of feeder roads & 5 \\
Lack of shed in the market & 6 \\
Lack of processing plant & 7 \\
Strike / Political unrest & \\
Traders & 1 \\
Unstable price & 2 \\
Selling on credit & 3 \\
Lack of capital & 4 \\
Lack of market place & 5 \\
High transport cost & 1 \\
Lack of market information &
\end{tabular}

\section{Conclusion and Recommendations}

It is found from the study that if the farmers sell their mango directly to the ultimate consumers then they will get more benefit, hut it would not be possible because intermediaries were engaged to transfer mango from the farmers' field to distant consumers. It may, thus can be concluded from the foregoing analysis that 
farmers' shares seemed to be very low in channel I, II, and Ill, while cost of marketing and middlemen margins were high in these channels. To enhance the share of the farmers, development of channel IV situation should he given priority incentives by government to help to perform more marketing activities in their jurisdiction on the one hand and to create competitive conditions for the intermediaries in favour of the farmers on the other.

On the basis of the above discussion, the following recommendations would be followed for efficient marketing of mango:

According to the farmer's opinion, price of mango is very low at peak harvesting period. Establishment of mango processing plant in the intensive growing areas may be are of the remedies of this problem and it ill ensure fair prices for the farmers. In this respect, new thrust on research must be in the direction of HYV (both summer and winter) for regular supply of mango in the processing mill.

Entrepreneurs should he encouraged to establish processing plant adjacent to mango growing areas. Provision of loan may be made through nationalized hank to the private sector for establishing processing mill in rural areas.

Darket information should be provided to the farmers regularly. If they get the market information about their product, they would be able to know the real situation of their product and could decide to take the produces to high price distant markets.

$>$ It would he better for the farmers in the area if they would organize themselves into cooperative. Cooperative movement as a process brings a producer one step closer to final user of his product. As an organized body, they would also acquire a better bargaining power for their products over the powerful middlemen that manipulate and control the price of mango in the marketing system.

\section{References}

BBS. 2004. Yearbook of Agricultural Statistics, Bangladesh Bureau of Statistics, Ministry of Planning, Govt. of the people's Republic of Bangladesh (Dhaka).

Chauhan, B.R.S., R.B.S. Tomar and A. K. Gupta. 1994. Economic Performance of Paddy Marketing Channels. A Case Study of Banda District of Uttar Pradesh. Journal of Agricultural Marketing 37(2): 6- 10.

Kohls, R.L. and J. N. Uhl. 1980. Marketing of Agricultural Product. Fifth Edition: Macmillan Publishing Co., INC.

Rajagopal. 1986. Economic Efficiency of Paddy Marketing System in Madhya Pradesh: A Case Study. Indian Journal of Agricultural Economics 41(4): 583-589. 